\title{
APPLICATION OF NATURAL ZEOLITE IN WASTEWATER TREATMENT - A REVIEW
}

\author{
Ž.Z. Tasić1, G.D. Bogdanovići" \\ ${ }^{1}$ University of Belgrade, Technical Faculty in Bor, V.J. 12, 19210 Bor, Serbia
}

(Received: October 24, 2019; Accepted: November 25, 2019)

\begin{abstract}
The environmental pollution is a major problem over the world. The large amount of pollutants formed during various industrial processes reaches the ecosystem. Thus, heavy metals, oils and other organic compounds are responsible for water contamination. It is known that heavy metals have toxic effect on the environment. Additionally, they are non-degradable and have ability to reach the living organisms through the food chain. Among different methods, the adsorption is widely used in wastewater treatment due to simplicity of the process and efficiency in the removal of pollutants. Natural zeolites from different deposits have shown good selectivity for heavy metal ions. Additionally, they are environmentally friendly, low-cost and have high ion exchange capacity.
\end{abstract}

Key words: Wastewater treatment; Pollutants; Natural zeolite; Adsorption.

\section{Introduction}

Due to the fast development of industry, a large amount of wastewater has been produced. The wastewater contains various pollutants including heavy metals, oils and organics that have toxic effect on the environment [1]. Beside industrial processes, such as melting, galvanizing, electrolysis, wastewater originates from domestic sewage and agriculture, too [2-5]. The removal of pollutants from water is the subject of many studies [6-8]. Researchers are constantly working to determine a suitable and efficient method for wastewater treatment.

It is known that heavy metals are toxic and are non-degradable. Thus, they have ability to reach the living organisms through the food chain $[9,10]$. Having this in mind, they must be eliminated from water or reduced [11].

Different efficient techniques including solvent extraction, membrane filtration, chemical precipitation, ion exchange and adsorption can be used to remove contaminants from water and they have drawn significant interest of researchers [12,
13]. Due to the simplicity of the process and the high efficiency of pollutant removal, adsorption is an increasingly examined method for wastewater treatment. In addition, various materials such as zeolites, clays and by-products from different industries can be used as adsorbents. Except these natural materials, synthetic polymer adsorbents are commercially available. Activated carbon is also a significant adsorbent derived from natural organic materials. Characteristics of activated carbon that make it effective in removing pollutants from aqueous solutions are the large specific surface area, porous structure and thermostability [14]. However, due to the high cost of this adsorbent, researchers are still trying to find new, cheaper and more efficient adsorbents. Based on researches [15-17], it has been observed that various agricultural and industrial by-products can be successfully used to remove pollutants from aquatic environments. In addition, the cost and availability of these materials have an impact on the selection of the appropriate adsorbent. Among them, zeolites are the mostly used adsorbents because they are environmentally friendly, low

\#Corresponding author: gbogdanovic@tfbor.bg.ac.rs

doi: 10.5937/JMMA1901067T 
cost, possess good selectivity for different cations and have high ion exchange capacity which is accompanied with a release of non-toxic exchangeable cations $\left(\mathrm{K}^{+}, \mathrm{Na}^{+}, \mathrm{Ca}^{2+}\right.$ and $\left.\mathrm{Mg}^{2+}\right)$ to the environment [18].

\section{The structure of zeolites and their characteristics}

Considering physical properties, crystal structure and morphology of natural zeolites as well as types of exchangeable cations in zeolite structure, they are divided into seven main groups [19]. In the 1970s, natural zeolites have attracted the attention among numerous researchers because of their ability to remove heavy metals such as strontium and cesium [20]. Analcime, chabazite, clinoptilolite, erionite, mordenite and phillipsite are the most common natural zeolites. One of the most investigated zeolite in wastewater treatment is clinoptilolite [21-23]. In general, chemical formula of zeolites is given as in the following equation [1]:

$M_{x / n}\left[A_{x} S i_{y} O_{2(x+y)}\right] \cdot \mathrm{pH}_{2} \mathrm{O}$

where $\mathrm{M}=\mathrm{Na}, \mathrm{K}, \mathrm{Li}$ and / or $\mathrm{Ca}, \mathrm{Mg}, \mathrm{Ba}, \mathrm{Sr}, \mathrm{n}$ is the charge of the cation $Y / X=1-6, P / X=1-4$.

Zeolites are microporous materials with cavities less than $2 \mathrm{~nm}$. Their structure is based on a threedimensional framework of tetrahedral units $\left(\mathrm{SiO}_{4}{ }^{4-}\right.$ and $\left.\mathrm{AlO}_{4}{ }^{5}\right)$ connected by sharing one oxygen atom [24]. Such a well-defined three-dimensional structure contains channels, cavities and pores of molecular dimensions within which the catalytically active centers of are located [25]. Active centers are available only to molecules whose dimensions are smaller or approximately equal to the dimensions of the pores themselves (molecular sieve effect) $[4,26]$. The aluminum ion is small enough to occupy a position in the center of the tetrahedron composed of 4 oxygen atoms, while the isomorphic replacement of $\mathrm{Si}^{4+}$ by $\mathrm{Al}^{3+}$ ions produces a negative charge on the lattice. The negative charge of the lattice is balanced by exchangeable cations, $\mathrm{Na}^{+}, \mathrm{K}^{+}$or $\mathrm{Ca}^{2+}$, which are relatively harmless [27, 28]. Furthermore, a characteristic of these cations is their mobility due to weak electrostatic interactions with the alumosilicate lattice. Therefore, there is a possibility of ion exchange between zeolites and ions present in aqueous solutions.

Due to structural properties such as large specific surface, well-defined micropores in molecular dimensions, as well as high chemical and physical stability (e.g., thermal and mechanical) [29], and sorption characteristics [30], natural zeolites are interesting materials for application in wastewater treatment [31], in petroleum refining [32], in agriculture [33], in biotechnology and medicine [34].

The reaction of ion exchange in aqueous solution occurs according to the following equation:

$z R^{r+}(a q)+r Z^{z^{+}}(s) \rightarrow z R^{r+}(s)+r Z^{Z^{+}}(a q)$

where $r$ is the charge of the cation $R$ contained in the solution, while $z$ is the charge of the moving cation $\mathrm{Z}$ in the zeolite.

The Si/Al ratio, specific surface area and pore size are also important features that affect the adsorption capacity of zeolites. This is the main reason that different tests on clinoptilolite obtained from different deposits may show different results. Although there may be some variations in the chemical structure of clinoptilolites from different deposits, as well as different mineral impurities in different samples, the main reason for the difference in the obtained results is the different physical and chemical conditions used in the experiments.

Table 1. Cation exchange capacity for different zeolites $[35,36]$

\begin{tabular}{lccl}
\hline Zeolite & $\begin{array}{c}\text { Si/Al } \\
\text { ratio }\end{array}$ & $\begin{array}{c}\mathrm{CEC}, \\
\mathrm{meq} / \mathrm{g}\end{array}$ & Main cation \\
\hline Chabazite & $1.4-4.0$ & $2.5-4.7$ & $\mathrm{Na}, \mathrm{K}, \mathrm{Ca}$ \\
Clinoptilolite & $4.0-5.7$ & $2.0-2.6$ & $\mathrm{Na}, \mathrm{K}, \mathrm{Ca}$ \\
Mordenite & $4.0-5.7$ & $2.0-2.4$ & $\mathrm{Na}, \mathrm{K}, \mathrm{Ca}$ \\
Erionite & $2.6-3.8$ & $2.7-3.4$ & $\mathrm{~K}, \mathrm{Na}, \mathrm{Ca}, \mathrm{Mg}$ \\
Ferrierite & $4.9-5.7$ & $2.1-2.3$ & $\mathrm{Ca}$ \\
Laumontite & $1.9-2.4$ & $3.8-4.3$ & $\mathrm{Na}, \mathrm{K}, \mathrm{Mg}$ \\
\hline
\end{tabular}


Additionally, in Table 1, it is shown the Si/Al ratio and cation exchange capacity (CEC) for some natural zeolites $[35,36]$.
Also, the chemical composition of zeolites from different deposits is shown in Table 2.

Table 2. Chemical composition of zeolites from different deposits

\begin{tabular}{|c|c|c|c|c|c|c|c|c|c|}
\hline \multicolumn{10}{|c|}{ Components (wt \%) } \\
\hline Zeolite & $\mathrm{SiO}_{2}$ & $\mathrm{Al}_{2} \mathrm{O}_{3}$ & $\mathrm{Fe}_{2} \mathrm{O}_{3}$ & $\mathrm{Na}_{2} \mathrm{O}$ & $\mathrm{K}_{2} \mathrm{O}$ & $\mathrm{CaO}$ & $\mathrm{MgO}$ & $\mathrm{IL}$ & Reference \\
\hline Clinoptilolitea & 65.63 & 12.97 & 1.48 & 1.20 & 1.33 & 3.21 & 1.41 & 12.96 & [37] \\
\hline Clinoptiloliteb & 64.20 & 11.67 & 1.03 & 2.36 & 3.84 & 7.42 & 0.35 & 8.66 & [38] \\
\hline Clinoptilolitec & 64.93 & 13.39 & 2.07 & 2.40 & 1.30 & 2.00 & 1.09 & 9.63 & [39] \\
\hline Clinoptilolited & 70.08 & 11.72 & 0.67 & 0.55 & 3.50 & 3.18 & 0.71 & 9.45 & [27] \\
\hline Clinoptilolite & 64.51 & 11.25 & 0.97 & 3.60 & 1.21 & 4.38 & 0.60 & 13.14 & [40] \\
\hline Clinoptilolitef & 67.16 & 12.30 & 2.30 & 0.66 & 2.28 & 2.91 & 1.10 & 1 & [41] \\
\hline Clinoptiloliteg & 65.52 & 9.89 & 1.04 & 2.31 & 0.88 & 3.17 & 0.61 & 1 & [42] \\
\hline Clinoptiloliteh & 68.26 & 12.99 & 1.37 & 0.64 & 4.11 & 2.09 & 0.83 & I & [43] \\
\hline Clinoptilolitei & $65.0-71.3$ & $11.5-13.1$ & $0.7-1.9$ & $0.2-1.3$ & $2.2-3.4$ & $2.7-5.2$ & $0.6-1.2$ & 1 & [22] \\
\hline Clinoptilolitej & 63.60 & 11.81 & 1.74 & 0.40 & 4.40 & 7.35 & 0.69 & 9.81 & [74] \\
\hline Clinoptilolitek & 66.57 & 13.13 & 2.30 & 1.27 & 1.17 & 3.85 & 0.56 & 11.05 & \\
\hline Clinoptilolitel & 65.89 & 12.86 & 2.06 & 0.97 & & 4.90 & 0.95 & 11.26 & \\
\hline
\end{tabular}

a-from Serbia, $b$ - from Bulgaria, c - from Croatia, $d$ - from Turkey, e - from Argentina, $f$ - from Slovakia, $g$ - from China, $\mathrm{h}$ - from Australia, i - from Slovakia, j - from Serbia (Vranjska Banja), k - from Serbia (Brus), I - from Romania (Baia Mare), / - no data, IL - ignition loss.

\section{Wastewater treatment using natural zeolites}

Adsorption in wastewater treatment is considered as an effective technique in comparison with other methods. The experimental conditions for removal of contaminants by adsorption process are very important. The ability of zeolite to be regenerated and its reuse is very important for the environment because this prevents the generation of new waste material [44]. Many researchers are dealing with the application of natural zeolites in removing metal ions from wastewater $[22,23,44$, $45,46]$. Additionally, clinoptilolite has been investigated as adsorbent for the removal of dyes, phenols and phenol derivatives from aqueous solutions, as summarized in Table 3.

The clinoptilolite was found to be effective in removing metal cations such as $\mathrm{Al}^{3+}, \mathrm{Cd}^{2+}, \mathrm{Cu}^{2+}$, $\mathrm{Fe}^{3+}, \mathrm{Ni}^{2+}, \mathrm{Pb}^{2+}$ and $\mathrm{Zn}^{2+}$ from copper mine wastewater [54]. It was observed that clinoptilolite has a high selectivity for heavy metal ions following the order: $\mathrm{Pb}^{2+}>\mathrm{Cd}^{2+}>\mathrm{Cu}^{2+}>\mathrm{Co}^{2+}>\mathrm{Cr}^{3+}>\mathrm{Zn}^{2+}$ $>\mathrm{Ni}^{2+}>\mathrm{Hg}^{2+}[20]$.
The ability of clinoptilolite to uptake $\mathrm{Cu}^{2+}$ from aqueous solution at different temperatures $(25,45$ and $60{ }^{\circ} \mathrm{C}$ ), at different $\mathrm{pH}$ values (1-4) and at different agitation speed $(0,100,200,400 \mathrm{rpm})$ was studied by Stylianou et al. [28]. The best efficiency of zeolite in removing copper ions was achieved at $\mathrm{pH} 4$. Also, it has been observed that the agitation speed influences on the degree of removal. Specifically, the highest removal efficiency $(37.3 \%)$ was achieved at an agitation rate of $400 \mathrm{rpm}$ at $25^{\circ} \mathrm{C}$.

In addition to the above parameters, the value of Si/Al molar ratio as well as zeolite porosity also affects the cation exchange capacity. As Si/Al ratio is higher, the cation exchange capacity is lower $[55,56]$. The ion exchange capacity can range from 0.6 to $2.3 \mathrm{meq} / \mathrm{g}$ [1]. As the specific surface area of the adsorbent is larger, the particles are smaller and the pore volume is larger. Most researchers have found that adsorbents with a smaller particle size cause a higher adsorption capacity due to larger specific surface area of the adsorbents [27, 30, 57-59], while others have noted that particle size does not affect the 
adsorption process $[60,61]$. The influence of cations from aqueous solutions is shown in adsorbent particle size on the removing of metal Table 4.

Table 3. Adsorption ability of natural zeolite

\begin{tabular}{llcc}
\hline Adsorbent & Material & Adsorption $(\mathrm{mg} / \mathrm{g})$ & Reference \\
\hline Clinoptilolite & Methylene blue & 19.9 & {$[43]$} \\
Clinoptilolite & Rhodamine B & 12.4 & \\
Clinoptilolite & Malachite green & 19.7 & {$[47]$} \\
Clinoptilolite & Toluidine blue O & $33.0-58.7$ & {$[48]$} \\
Turkish clinoptilolite & Reactive Black 5 & 61.0 & {$[49]$} \\
& Red 239 & 111.0 & \\
Turkish clinoptilolite modified & Yellow 176 & 89.0 & \\
with quaternary amine & Everzol Black & 2.9 & {$[50]$} \\
surfactant (HTAB) Everzol Red & Everzol Yellow & 3.7 & \\
Australian natural zeolite & Humic acid & 7.6 & \\
& & 68.0 & {$[51]$} \\
Jordanian zeolite & phenol & $5.00-32.60$ & {$[52]$} \\
Mexican clinoptilolite & Phenol & $6.50-12.76$ & {$[53]$} \\
& p-nitrophenol & $0.58-01.44$ & \\
\hline
\end{tabular}

Table 4. Particle size effects of natural zeolite on adsorption of heavy metals

\begin{tabular}{|c|c|c|c|c|c|}
\hline & Metal adsorl & & & & Reference \\
\hline Particle size of clinoptilolite, $(\mu \mathrm{m})$ & $\mathrm{Pb}^{2+}$ & $\mathrm{Cd}^{2+}$ & $\mathrm{Zn}^{2+}$ & $\mathrm{Cu}^{2+}$ & \\
\hline $160-600$ & $1.29 \mathrm{mg} / \mathrm{g}$ & $1.02 \mathrm{mg} / \mathrm{g}$ & 1 & 1 & [20] \\
\hline $600-1000$ & $1.28 \mathrm{mg} / \mathrm{g}$ & $1.01 \mathrm{mg} / \mathrm{g}$ & 1 & 1 & \\
\hline $1000-2000$ & $1.27 \mathrm{mg} / \mathrm{g}$ & $0.98 \mathrm{mg} / \mathrm{g}$ & 1 & 1 & \\
\hline 53-106 & 1 & 1 & $\begin{array}{l}2.110^{\mathrm{a}} \mathrm{mg} / \mathrm{g} \\
4.406^{\mathrm{b}} \mathrm{mg} / \mathrm{g}\end{array}$ & I & [58] \\
\hline 106-212 & 1 & 1 & $\begin{array}{l}1.973^{\mathrm{a}} \mathrm{mg} / \mathrm{g} \\
4.141^{\mathrm{b}} \mathrm{mg} / \mathrm{g}\end{array}$ & 1 & \\
\hline $212-300$ & I & I & $\begin{array}{l}1.715^{\mathrm{a}} \mathrm{mg} / \mathrm{g} \\
4.056^{\mathrm{b}} \mathrm{mg} / \mathrm{g}\end{array}$ & I & \\
\hline$<90$ & 1 & 1 & 1 & $89.34 \%$ & [62] \\
\hline $90-325$ & 1 & 1 & 1 & $82.64 \%$ & \\
\hline $325-400$ & 1 & 1 & 1 & $78.33 \%$ & \\
\hline
\end{tabular}

I - no data; a - Bigadic zeolite; $b$ - Gordes zeolite

The $\mathrm{pH}$ value of the test solutions is an important parameter affecting the adsorption process. The activity of the adsorbent functional groups, then the type of complex formed between the metal ions and the adsorbent, depends on the environment in which the adsorption process takes place. Namely, in very acidic solutions, the protonation of the functional groups occurs, whereby they become positively charged and thus weak the attractive forces between the metal and the adsorbent. Deprotonation of adsorbent functional groups occurs at higher $\mathrm{pH}$ values, and such groups more strongly attract metal ions forming a complex $[63,64]$. As mentioned, the $\mathrm{pH}$ value of the solution is a significant parameter that affects the degree of metal ions removal. Motsi et al. [26], in their work, examined the effect of solution $\mathrm{pH}$ on the removal of $\mathrm{Cu}^{2+}$. According to the obtained results, the adsorption of copper ions from the solution increases with increasing $\mathrm{pH}$ of 
the solution. In acidic solutions, $\mathrm{H}^{+}$ions are more efficiently adsorbed on zeolite active sites than metal ions. As the $\mathrm{pH}$ of the solution increases, the concentration of $\mathrm{H}^{+}$ions decreases and therefore more metal ions are adsorbed on to zeolite [30].

In the paper of Ding et al. [65], the possibility of using bentonite as adsorbent to remove copper ions was investigated. The study was conducted in the $\mathrm{pH}$ range from 1.0 to 9.0. It was observed that the $\mathrm{pH}$ of the solution affected the degree of $\mathrm{Cu}^{2+}$ adsorption. In the acidic environment, the lowest degree of adsorption is achieved, which can be explained by the competition of $\mathrm{Cu}^{2+}$ and $\mathrm{H}^{+}$ions that tend to adsorb at the same zeolite active sites. A further increase in the $\mathrm{pH}$ value showed an increase in the degree of adsorption. At a pH range of 3.0 to $7.0, \mathrm{Na}^{+}, \mathrm{K}^{+}, \mathrm{Ca}^{2+}$ and $\mathrm{Mg}^{2+}$ ions are exchanged with $\mathrm{Cu}^{2+}$ ions from solution, while adsorption of $\mathrm{Cu}^{2+}$ ions in the form of $\mathrm{Cu}(\mathrm{OH})_{2}$ is observed at $\mathrm{pH}>8.0$.

Table 5 lists the different types of adsorbents that can be used in the heavy metal removal process and their adsorption capacity.

Table 5. Adsorption of heavy metal ions on various zeolites

\begin{tabular}{|c|c|c|c|c|c|c|c|}
\hline Material & Metal & Adsorption & Reference & Material & Metal & Adsorption & Reference \\
\hline \multirow{4}{*}{$\begin{array}{l}\text { Sardınıan } \\
\text { clinoptilolite }\end{array}$} & $\mathrm{Cu}^{2+}$ & $0.340 \mathrm{meq} / \mathrm{g}$ & \multirow[t]{4}{*}[66]{} & \multirow[t]{9}{*}{ Clinoptilolite } & \multirow[t]{3}{*}{$\mathrm{Cu}^{2+}$} & $0.44 \mathrm{mg} / \mathrm{g}(\mathrm{pH} 2.5)$ & \multirow[t]{9}{*}{ [26] } \\
\hline & $\mathrm{Cd}^{2+}$ & $0.05-0.190 \mathrm{meq} / \mathrm{g}$ & & & & $0.54 \mathrm{mg} / \mathrm{g}(\mathrm{pH} 3.5)$ & \\
\hline & $\mathrm{Pb}^{2+}$ & $0.27-1.200 \mathrm{meq} / \mathrm{g}$ & & & & $0.54 \mathrm{mg} / \mathrm{g}(\mathrm{pH} 4.5)$ & \\
\hline & $\mathrm{Zn}^{2+}$ & $0.100 \mathrm{meq} / \mathrm{g}$ & & & \multirow[t]{3}{*}{$\mathrm{Zn}^{2+}$} & $1.60 \mathrm{mg} / \mathrm{g}(\mathrm{pH} 2.5)$ & \\
\hline Clinoptilolite & $\mathrm{Cd}^{2+}$ & $0.12-0.180 \mathrm{meq} / \mathrm{g}$ & [67] & & & $2.21 \mathrm{mg} / \mathrm{g}(\mathrm{pH} 3.5)$ & \\
\hline Turkish & $\mathrm{Co}^{2+}$ & $0.448 \mathrm{meq} / \mathrm{g}$ & [68] & & & $2.14 \mathrm{mg} / \mathrm{g}(\mathrm{pH} 4.5)$ & \\
\hline \multirow[t]{3}{*}{ clinoptilolite } & $\mathrm{Cu}^{2+}$ & $0.282 \mathrm{meq} / \mathrm{g}$ & & & \multirow[t]{3}{*}{$\mathrm{Mn}^{2+}$} & $0.37 \mathrm{mg} / \mathrm{g}(\mathrm{pH} 2.5)$ & \\
\hline & $\mathrm{Zn}^{2+}$ & $0.268 \mathrm{meq} / \mathrm{g}$ & & & & $0.52 \mathrm{mg} / \mathrm{g}(\mathrm{pH} 3.5)$ & \\
\hline & $\mathrm{Mn}^{2+}$ & $0.153 \mathrm{meq} / \mathrm{g}$ & & & & $0.52 \mathrm{mg} / \mathrm{g}(\mathrm{pH} 2.5)$ & \\
\hline \multirow{5}{*}{$\begin{array}{l}\text { Brazilian } \\
\text { scolecite }\end{array}$} & $\mathrm{Cr}^{3+}$ & $5.810 \mathrm{meq} / \mathrm{g}$ & \multirow[t]{5}{*}{ [69] } & \multirow{5}{*}{$\begin{array}{l}\text { Turkish natural } \\
\text { clinoptilolite } \\
\text { CC1 } \\
\text { CC2 } \\
\text { CC3 }\end{array}$} & \multirow[t]{5}{*}{$\mathrm{Zn}^{2+}$} & $21.200 \mathrm{mg} / \mathrm{g}$ & \multirow[t]{5}{*}{ [59] } \\
\hline & $\mathrm{Ni}^{2+}$ & $2.080 \mathrm{meq} / \mathrm{g}$ & & & & $20.800 \mathrm{mg} / \mathrm{g}$ & \\
\hline & $\mathrm{Cd}^{2+}$ & $1.780 \mathrm{meq} / \mathrm{g}$ & & & & $22.200 \mathrm{mg} / \mathrm{g}$ & \\
\hline & $\mathrm{Mn}^{2+}$ & $4.000 \mathrm{meq} / \mathrm{g}$ & & & & $17.900 \mathrm{mg} / \mathrm{g}$ & \\
\hline & & & & & & & \\
\hline \multirow{3}{*}{$\begin{array}{l}\text { Mexican } \\
\text { clinoptilolite }\end{array}$} & $\mathrm{Cd}^{2+}$ & $0.15-0.42 \mathrm{mg} / \mathrm{g}$ & \multirow[t]{9}{*}{ [70] } & \multirow[t]{3}{*}{ Natural zeolite } & $\mathrm{Zn}^{2+}$ & $13.060 \mathrm{mg} / \mathrm{g}$ & \multirow[t]{3}{*}{ [72] } \\
\hline & $\mathrm{Ni}^{2+}$ & $0.10-0.31 \mathrm{mg} / \mathrm{g}$ & & & \multirow[t]{2}{*}{$\mathrm{Cu}^{2+}$} & $25.040 \mathrm{mg} / \mathrm{g}$ & \\
\hline & $\mathrm{Zn}^{2+}$ & $0.03-0.18 \mathrm{mg} / \mathrm{g}$ & & & & & \\
\hline \multirow{3}{*}{$\begin{array}{l}\text { Sodium } \\
\text { modified } \\
\text { Mexican } \\
\text { clinoptilolite }\end{array}$} & $\mathrm{Cd}^{2+}$ & $0.15-0.42 \mathrm{mg} / \mathrm{g}$ & & \multirow[t]{3}{*}{ Clinoptilolite } & $\mathrm{Pb}^{2+}$ & $101.000 \mathrm{mg} / \mathrm{g}$ & \multirow[t]{3}{*}{ [73] } \\
\hline & $\mathrm{Ni}^{2+}$ & $0.10-0.31 \mathrm{mg} / \mathrm{g}$ & & & $\mathrm{Cu}^{2+}$ & $11.700 \mathrm{mg} / \mathrm{g}$ & \\
\hline & $\mathrm{Zn}^{2+}$ & $0.03-0.18 \mathrm{mg} / \mathrm{g}$ & & & $\mathrm{Cr}^{3+}$ & $6.800 \mathrm{mg} / \mathrm{g}$ & \\
\hline Acid modified & $\mathrm{Cd}^{2+}$ & $0.15-0.36 \mathrm{mg} / \mathrm{g}$ & & \multirow[t]{3}{*}{ Clinoptilolite } & \multirow[t]{3}{*}{$\mathrm{Cu}^{2+}$} & $9.544 \mathrm{mg} / \mathrm{g}$ & \multirow[t]{3}{*}[44]{} \\
\hline Mexican & $\mathrm{Ni}^{2+}$ & $0.10-0.28 \mathrm{mg} / \mathrm{g}$ & & & & & \\
\hline clinoptilolite & $\mathrm{Zn}^{2+}$ & $0.03-0.18 \mathrm{mg} / \mathrm{g}$ & & & & & \\
\hline \multirow[t]{4}{*}{ Clinoptilolite } & $\mathrm{Al}^{3+}$ & $0.22 \mathrm{mg} / \mathrm{g}$ & \multirow[t]{4}{*}{ [54] } & Clinoptilolite VB & \multirow[t]{4}{*}{$\mathrm{Cu}^{2+}$} & $7.750 \mathrm{mg} / \mathrm{g}$ & \multirow[t]{4}{*}[74]{} \\
\hline & $\mathrm{Fe}^{3+}$ & $0.02 \mathrm{mg} / \mathrm{g}$ & & Clinoptilolite I & & $8.510 \mathrm{mg} / \mathrm{g}$ & \\
\hline & $\mathrm{Cu}^{2+}$ & $0.13 \mathrm{mg} / \mathrm{g}$ & & Clinoptilolite BM & & $11.180 \mathrm{mg} / \mathrm{g}$ & \\
\hline & $\mathrm{Zn}^{2+}$ & $0.16 \mathrm{mg} / \mathrm{g}$ & & & & & \\
\hline $\begin{array}{l}\text { Serbian } \\
\text { clinoptilolite }\end{array}$ & $\mathrm{Cu}^{2+}$ & $5.25 \mathrm{mg} / \mathrm{g}$ & [71] & & & & \\
\hline
\end{tabular}


Zdenska et al. [44] examined the possibility of using clinoptilolite to remove copper ions from synthetic solutions, at pH 3.5. It has been observed that, as the initial copper concentration in aqueous solution increases, adsorption capacity also increases, while the degree of adsorption decreases. In addition, the effect of the used adsorbent dosage on the degree of copper ion removal was investigated. As the dosage of adsorbent increases, the removal efficiency increases too. The maximum removal efficiency of $\mathrm{Cu}^{2+}$ was $61.8 \%$ at adsorbent dosage $10 \mathrm{~g}$. This can be explained by an increase in the number of active sites where copper ion can be adsorbed. Similar conclusions were obtained by Courh [59], who investigated the adsorption of $\mathrm{Zn}^{2+}$ from $\mathrm{ZnSO}_{4} \cdot 7 \mathrm{H}_{2} \mathrm{O}$ solution on a natural zeolite. Studies have shown that the initial concentration of heavy metal ions and the temperature of the solution have an important role in the adsorption process. As the temperature of the solution increases, the degree of adsorption of heavy metal ions rises too. At a temperature of $90^{\circ} \mathrm{C}$, the removal efficiency of $\mathrm{Zn}^{2+}$ was $77.9 \%$ [59].

Also, it has been observed that adsorption capacity and selectivity depend primarily on the type of zeolite used in various studies. In the work of Okia and Kavanage [75], two natural zeolites, clinoptilolite and chabasite, were used to remove $\mathrm{Pb}^{2+}, \mathrm{Cd}^{2+}, \mathrm{Cu}^{2+}, \mathrm{Zn}^{2+}, \mathrm{Cr}^{2+}, \mathrm{Ni}^{2+}$ and $\mathrm{Co}^{2+}$ ions. Different selectivity of clinoptilolite and chabasite towards heavy metal ions was observed, namely $\mathrm{Pb}>\mathrm{Cu}>\mathrm{Cd}>\mathrm{Zn}>\mathrm{Cr}>\mathrm{Co}>\mathrm{Ni}$ for clinoptilolite and $\mathrm{Pb}>\mathrm{Cd}>\mathrm{Zn}>\mathrm{Co}>\mathrm{Cu}>\mathrm{Ni}>\mathrm{Cr}$ for chabasite.

In many studies, the adsorption process of single heavy metal ions has been analyzed, although wastewater most often contains multiple different ions between which there may be competition regarding zeolite binding. The natural zeolite, clinoptilolite, has been investigated for the removal of $\mathrm{Pb}^{2+}, \mathrm{Ni}^{2+}, \mathrm{Cu}^{2+}$, and $\mathrm{Zn}^{2+}$ ions from onecomponent and multi-component solutions. The maximum adsorption capacities of clinoptilolite in one-component solutions were $76,8,7$, and 5 $\mathrm{mg} / \mathrm{g}$ for $\mathrm{Pb}^{2+}, \mathrm{Zn}^{2+}, \mathrm{Cu}^{2+}$, and $\mathrm{Ni}^{2+}$, respectively, while these values were significantly smaller in the multi-component solution and were, respectively, $31,3.5,0.7$ and $0.5 \mathrm{mg} / \mathrm{g}$ [76]. Additionally, Li et al. [54], in their study analyzed the ability of clinoptilolite as adsorbent to remove $\mathrm{Al}^{3+}, \mathrm{Cu}^{2+}$, $\mathrm{Fe}^{3+}$ and $\mathrm{Zn}^{2+}$ ions from natural mine waters. The duration of the experiments was $24 \mathrm{~h}$ at $\mathrm{pH} 3.3$.

In the test solution, the concentrations of heavy metal ions were $24 \mathrm{mg} / \mathrm{dm}^{3}, 20.5 \mathrm{mg} / \mathrm{dm}^{3}, 2.76$ $\mathrm{mg} / \mathrm{dm}^{3}$ and $40 \mathrm{mg} / \mathrm{dm}^{3}$ for $\mathrm{Al}^{3+}, \mathrm{Cu}^{2+}, \mathrm{Fe}^{3+}$ and $\mathrm{Zn}^{2+}$ respectively. Based on the obtained results, $90 \% \mathrm{Al}^{3+}, 64 \% \mathrm{Cu}^{2+}, 82 \% \mathrm{Fe}^{3+}$ and $40 \% \mathrm{Zn}^{2+}$ were removed from the test solution. The initial $\mathrm{pH}$ of the solution may affect the selectivity of the zeolite under test to certain metal ions in solution. Panajotova [27] concluded that, for the removal of copper from aqueous solutions on clinoptilolite from Bulgaria, the optimum $\mathrm{pH}$ value is 5 . The natural zeolite from Jordan was also examined as adsorbent for the removal of $\mathrm{Cu}^{2+}$ and $\mathrm{Cd}^{2+}$ ions from synthetic two-component solutions, at $\mathrm{pH}=6$ [77]. Higher adsorption capacity for $\mathrm{Cd}^{2+}(25.5$ $\mathrm{mg} / \mathrm{g}$ ) was achieved compared to $\mathrm{Cu}^{2+}$ ions (14.3 $\mathrm{mg} / \mathrm{g}$ ). Concerning the selectivity of natural zeolite tuff from Croatia for the removal of $\mathrm{Zn}^{2+}, \mathrm{Pb}^{2+}$ and $\mathrm{Cu}^{2+}$ ions, Perić et al. [78] determined the following order: $\mathrm{Pb}^{2+}, \mathrm{Cu}^{2+}>\mathrm{Zn}^{2+}$. Also, Sprynskyy et al. [30] investigated the removal of heavy metals $\left(\mathrm{Ni}^{2+}\right.$, $\mathrm{Cu}^{2+}, \mathrm{Pb}^{2+}$ and $\mathrm{Cd}^{2+}$ ) under static conditions from single- and multi-component aqueous solutions by raw and pretreated clinoptilolites. The obtained results revealed that there are no differences in removing ions as $\mathrm{Cu}^{2+}, \mathrm{Pb}^{2+}$ and $\mathrm{Cd}^{2+}$ in singleand multi-component solutions. However, the adsorption of $\mathrm{Ni}^{2+}$ from multi-component solution is decreased in comparison to the single-component due to the competition with other cations in the solution. The maximum sorption capacity of $\mathrm{Cd}^{2+}$ was $4.22 \mathrm{mg} / \mathrm{g}$ at initial concentration of $80 \mathrm{mg} / \mathrm{L}$ and $27.7,25.76$ and $13.03 \mathrm{mg} / \mathrm{g}$ at $800 \mathrm{mg} / \mathrm{L}$ for $\mathrm{Pb}^{2+}, \mathrm{Cu}^{2+}$ and $\mathrm{Ni}^{2+}$.

Turkman et al. [79] studied the removal of heavy metals $\left(\mathrm{Pb}^{2+}, \mathrm{Cd}^{2+}, \mathrm{Ni}^{2+}\right.$ and $\left.\mathrm{Zn}^{2+}\right)$ in synthetic and real wastewater using activated and non-activated natural clinoptilolite. The researchers obtained better results with activated zeolite than 
with non-activated clinoptilolite. Furthermore, the adsorption ability of Bigadic and Gordes zeolite in order to uptake $\mathrm{Cd}^{2+}$ and $\mathrm{Ni}^{2+}$ ions was compared. The same was done in the investigation by Oren and Kaya [80]. By using Gordes zeolite the removal efficiency for $\mathrm{Cd}^{2+}$ was $46 \%$ while $\mathrm{Cd}^{2+}$ was not removed effectively by Bigadic zeolite after 90 min contact time. For $\mathrm{Ni}^{2+}$ removal, the obtained efficiency was $40 \%$ for both Bigadic and Gordes zeolite. Additionally, Oren and Kaya [80] in their study showed that the removal efficiency of Gordes zeolite is twice higher than that of Bigadic zeolite. In this paper, it has been examined the removal of $\mathrm{Cu}^{2+}$ and $\mathrm{Cd}^{2+}$ ions. The initial metal concentration was in the range of $100-600 \mathrm{mg} / \mathrm{L}$ at $\mathrm{pH} 6$, the adsorbent dosage was $5.0 \mathrm{~g}$. The capability of adsorption was found to be stable and reached the maximum value at concentration $100 \mathrm{mg} / \mathrm{L}$. The percentage of $\mathrm{Cu}^{2+}$ and $\mathrm{Cd}^{2+}$ removal decreases by increasing initial metal concentration. For $\mathrm{Cd}^{2+}$ and $\mathrm{Cu}^{2+}$ the adsorption capacities were 25.9 and 14.3 $\mathrm{mg} / \mathrm{g}$ [77].

The sorption behavior of natural zeolite (clinoptilolite) for the removal of metal ions $\mathrm{Cd}, \mathrm{Cu}$, $\mathrm{Ni}, \mathrm{Pb}$ and $\mathrm{Zn}$ has been studied. Metal concentration in solution ranging from $50-300$ $\mathrm{mg} / \mathrm{L}$. Clinoptilolite sorbed approximately 32,75 , 28, 99 and $59 \%$ of the added $\mathrm{Cd}, \mathrm{Cu}, \mathrm{Ni}, \mathrm{Pb}$ and $\mathrm{Zn}$ metal, respectively. The selectivity of clinoptilolite can be given as: $\mathrm{Pb}>\mathrm{Cu}>\mathrm{Zn}>\mathrm{Cd}>\mathrm{Ni}$ [81].

Baker et al. [82] investigated the uptake capacity of heavy metals ions $\mathrm{Cr}^{3+}, \mathrm{Cd}^{2+}, \mathrm{Cu}^{2+}$ and $\mathrm{Pb}^{2+}$ using Jordanian zeolite at solution $\mathrm{pH} 3.0$ (adsorbent dosage $5.0 \mathrm{~g}$ ). The Jordanian zeolite presented high selectivity for the discharge of $\mathrm{Pb}^{2+}$ as approximately $98 \%$ achieved within 90 minutes, while $96 \%$ of $\mathrm{Cr}^{3+}$, $\mathrm{Cu}^{2+}$ and $\mathrm{Cd}^{2+}$ removed within 5 h.

Alvarez-Ayuso et al. [56] compared the sorption behavior of natural clinoptilolite and synthetic NaP1 zeolites for $\mathrm{Cr}^{3+}, \mathrm{Ni}^{2+}, \mathrm{Zn}^{2+}, \mathrm{Cu}^{2+}$ and $\mathrm{Cd}^{2+}$ in regard to the purification of wastewater. The obtained results revealed that the synthetic zeolite has 10 times greater sorption capacity than natural zeolite. The adsorption capacity of synthetic zeolite was
$43.6 \mathrm{mg} / \mathrm{g}, 20.1 \mathrm{mg} / \mathrm{g}, 32.6 \mathrm{mg} / \mathrm{g}, 50.5 \mathrm{mg} / \mathrm{g}$ and $50.8 \mathrm{mg} / \mathrm{g}$ for $\mathrm{Cr}^{3+}, \mathrm{Ni}^{2+}, \mathrm{Zn}^{2+}, \mathrm{Cu}^{2+}$ and $\mathrm{Cd}^{2+}$, respectively.

In order to improve sorption abilities of raw natural zeolites, they can be modified by chemical treatments. Therefore, Cerjan-Stefanovic et al. [37] investigated the effect of pre-treatment of clinoptilolite from Serbia on the efficiency of $\mathrm{Zn}^{2+}$ removal. For the pre-treatment, solutions of $\mathrm{NaCl}$ or $\mathrm{CaCl}_{2}$ were used. It was observed that the pretreatment of zeolite enhanced the adsorption capacity of $\mathrm{Zn}^{2+}$.

The ability of acid-modified clinoptilolite to remove $\mathrm{Pb}^{2+}$ from the aqueous solutions was the goal of this paper. The clinoptilolite was modified using different concentrations of $\mathrm{H}_{2} \mathrm{SO}_{4}$ solution. The maximum uptake for $\mathrm{Pb}^{2+}$ was higher than $95 \%$ at $\mathrm{pH}$ solution around 5 . The lower removal capacity of $\mathrm{Pb}^{2+}$ at $\mathrm{pH} 2$ is due to the lower selectivity of clinoptilolite in acidic solutions and the strong competition between $\mathrm{Pb}^{2+}$ and $\mathrm{H}^{+}$for the exchangeable sites on zeolite framework. The decrease in $\mathrm{Pb}^{2+}$ sorption at higher $\mathrm{pH}$ values can be explained by the formation of hydrolyzed $\mathrm{Pb}^{2+}$ species which could precipitate [18].

In this paper, the removal of $\mathrm{Cd}^{2+}, \mathrm{Ni}^{2+}$ and $\mathrm{Zn}^{2+}$ using natural (clinoptilolite rich tuff from Mexico, ZPCli), sodium modified (ZPCliNa) and acid modified zeolites (ZPCliH) has been investigated. It was observed that after the treatment with $\mathrm{NaCl}$, sodium content increased 6 times whereas the content of other exchangeable cations in clinoptilolite decreased, especially for $\mathrm{K}^{+}$and $\mathrm{Ca}^{2+}$. Further, the treatment of zeolite with acid solution $\left(\mathrm{H}_{2} \mathrm{SO}_{4}\right)$, sodium was totally eliminated while the content of other cations decreased due to the introduction of $\mathrm{H}^{+}$in zeolite. According to the obtained results for $\mathrm{Ni}^{2+}$ and $\mathrm{Zn}^{2+}$, it is assumed that sorption occurs under the following mechanism: at initial $\mathrm{pH} 4$, the precipitation on the surface of ZPCli and ZPCliNa and ion exchange with native ions from zeolite with $\mathrm{Ni}^{2+}$ and $\mathrm{Zn}^{2+}$ from the solution. The selectivity of natural and modified zeolite follows the order: $\mathrm{Cd}^{2+}>\mathrm{Ni}^{2+}>\mathrm{Zn}^{2+}[70]$.

In accordance with investigations (Table 6), it is concluded that the adsorption of metal cations 
by using zeolite obeys pseudo-first-order or pseudo-second-order model.

Table 6. Kinetic parameters for metal cations removal

\begin{tabular}{|c|c|c|c|c|c|c|c|}
\hline Zeolite & Cation & $\begin{array}{c}\text { Isotherm } \\
\text { model }\end{array}$ & $\begin{array}{c}\text { Reaction } \\
\text { model }\end{array}$ & $\mathrm{k}_{1}(1 / \mathrm{min})$ & \multicolumn{2}{|c|}{$\mathrm{k}_{2}(\mathrm{~g} / \mathrm{mg} \cdot \mathrm{h})$} & Reference \\
\hline $\begin{array}{l}\text { Jordanian } \\
\text { zeolite }\end{array}$ & $\begin{array}{l}\mathrm{Cd}^{2+} \\
\mathrm{Cu}^{2+}\end{array}$ & $\begin{array}{c}\text { Langmuir } \\
\text { model }\end{array}$ & $\begin{array}{l}\text { Pseudo- } \\
\text { second }\end{array}$ & & \multicolumn{2}{|c|}{$\begin{array}{l}2.321 \\
1.716\end{array}$} & [77] \\
\hline $\begin{array}{l}\text { ZPCli } \\
\text { ZPCliNa } \\
\text { ZPCliH }\end{array}$ & $\mathrm{Cd}^{2+}$ & & $\begin{array}{l}\text { Pseudo- } \\
\text { second }\end{array}$ & & $\begin{array}{c}\mathrm{pH} 2 \\
18.188 \\
29.430 \\
16.420\end{array}$ & $\begin{array}{r}\text { pH } 10 \\
845.922 \\
346.057 \\
16.699\end{array}$ & [70] \\
\hline ZPCli & $\mathrm{Ni}^{2+}$ & & & & 27.102 & 284.240 & \\
\hline $\begin{array}{l}\text { ZPCliNa } \\
\text { ZPCliH }\end{array}$ & & & & & $\begin{array}{l}97.612 \\
29.782\end{array}$ & $\begin{array}{r}195.280 \\
16.962\end{array}$ & \\
\hline $\begin{array}{l}\text { ZPCli } \\
\text { ZPCliNa }\end{array}$ & $\mathrm{Zn}^{2+}$ & & & & $\begin{array}{l}30.280 \\
28.323\end{array}$ & $\begin{array}{r}11.083 \\
8.534\end{array}$ & \\
\hline ZPCliH & & & & & 62.876 & 4.040 & \\
\hline Zeolite & $\mathrm{Cu}^{2+}$ & & $\begin{array}{l}\text { Pseudo- } \\
\text { second }\end{array}$ & & 0.0016 & $\mathrm{mg} \cdot \min$ & [45] \\
\hline Clinoptilolite & $\begin{array}{l}\mathrm{Cu}^{2+} \\
\mathrm{Pb}^{2+} \\
\mathrm{Ni}^{2+} \\
\mathrm{Cd}^{2+}\end{array}$ & $\begin{array}{c}\text { Langmuir } \\
\text { model }\end{array}$ & $\begin{array}{l}\text { Pseudo- } \\
\text { second }\end{array}$ & & $\begin{array}{l}0.0011 \\
0.0007 \\
0.0041 \\
0.0226\end{array}$ & & [30] \\
\hline Clinoptilolite & $\begin{array}{l}\mathrm{Cd}^{2+} \\
\mathrm{Pb}^{2+} \\
\mathrm{Ni}^{2+} \\
\mathrm{Cu}^{2+} \\
\mathrm{Zn}^{2+}\end{array}$ & & First-order & $\begin{array}{l}0.01370 \\
0.05320 \\
0.01580 \\
0.02000 \\
0.02100\end{array}$ & & & [83] \\
\hline Clinoptilolite & $\mathrm{Pb}^{2+}$ & & First-order & 0.00035 & & & [47] \\
\hline
\end{tabular}

\section{Conclusion}

Analcime, chabazite, clinoptilolite, erionite, mordenite and phillipsite are the most common natural zeolites. Among them, clinoptilolite was the mostly investigated as adsorbent for wastewater purification. Due to significant adsorptive properties they can be used for the removal of different pollutants such as heavy metals, oil and organic contaminates. Natural zeolites are low cost adsorbents with excellent selectivity for various cations and good ion exchange capacity. The presence of non-toxic exchangeable cations in zeolite structure such as: $\mathrm{Na}^{+}, \mathrm{K}^{+}, \mathrm{Mg}^{2+}$ and $\mathrm{Ca}^{2+}$ makes the zeolites suitable for wastewater treatment. In order to improve the sorption properties, natural zeolites are modified. In accordance with that, researchers obtained a few times greater sorption capacities in comparison to the raw zeolite.

\section{Acknowledgements}

The authors gratefully acknowledge financial support from the Ministry of Education, Science and Technological Development of the Republic of Serbia through the Project No 172031.

\section{Reference list:}

[1] Wang, S., Peng, Y. (2010) Natural zeolites as effective adsorbents in water and wastewater 
treatment. Chemical Engineering Journal, 156, 11-24.

[2] Masindi, V., Gitari, W.M. (2015) Simultaneous removal of metal species from acidic aqueous solutions using cryptocrystalline magnesite/bentonite clay composite: an experimental and modelling approach. Journal of Cleaner Production, 39, 1-9.

[3] Kaparapu J., Narasimha Rao, G.M., Prasad, M.K. (2015) Marine algae as bio-sorbents. Journal of Algal Biomass Utilization, 63, 1619.

[4] Malamis, S., Katsou, E. (2013) A review on zinc and nickel adsorption on natural and modified zeolite, bentonite and vermiculite: Examination of process parameters, kinetics and isotherms. Journal of Hazardous Materials, 252-253, 428-461.

[5] Bilal, M., Ali Shah, J., Ashfaq, T., Gardazi, S.M.H., Tahir, A.A., Pervez, A., Haroon, H., Mahmood, Q. (2013) Waste biomass adsorbents for copper removal from industrial wastewater-A review. Journal of Hazardous Materials, 263, 322- 333.

[6] Ferreira, J., Oliveira, L., Ragozoni, M., Paulo da Silva, J., Ramalho, T. (2012) Adsorption of aromatic compounds under magnetic field influence. Water, Air, and Soil Pollution, 223, 3545- 3551.

[7] Lesmana, S.O., Febriana, N., Soetaredjo, F.E., Sunarso, J., Ismadji, S. (2009) Studies on potential applications of biomass for the separation of heavy metals from water and wastewater. Biochemical Engineering Journal, 44, 19-41.

[8] Pavlovic, I., Pérez, M.R., Barriga, C., Ulibarri, M.A. (2009) Adsorption of $\mathrm{Cu}^{2+}, \mathrm{Cd}^{2+}$ and $\mathrm{Pb}^{2+}$ ions by layered double hydroxides intercalated with the chelating agents diethylenetriaminepentaacetate and meso2,3-dimercaptosuccinate. Applied Clay Science, 43, 125-129.

[9] Alijani, H., Beyki, M.H., Shariatinia, Z., Bayat, M., Shemirani, F. (2014) A new approach for one stepsynthesis of magnetic carbon nanotubes/diatomite earth composite by chemical vapor deposition method: Application for removal of lead ions. Chemical Engineering Journal, 253, 456-463.

[10] Chen, G., Qiao, C., Wang, Y., Yao, J. (2014) Synthesis of magnetic gelatin and its adsorption property for $\mathrm{Cr}(\mathrm{VI})$. Industrial and Engineering Chemistry Research, 53, 1557615581.

[11] Hernández-Montoya, V., Pérez-Cruz, M.A., Mendoza-Castillo, D.I., Moreno-Virgen, M.R., Bonilla-Petriciolet, A. (2013) Competitive adsorption of dyes and heavy metals on zeolitic structures. Journal of Environmental Management, 116, 213-221.

[12] Barakat, M.A. (2011) New trends in removing heavy metals from industrial wastewater. Arabian Journal of Chemistry 4, 361-377.

[13] Khulbe, K.C., Matsuura, T. (2018) Removal of heavy metals and pollutants by membrane adsorption techniques. Applied Water Science, 8 (19), https://doi.org/ 10.1007/s13201-018-0661-6

[14] Fu, F., Wang, Q. (2011) Removal of heavy metal ions from wastewaters: A review. Journal of Environmental Management, 92, 407-418.

[15] Olorundare, O.F., Krause, R.W.M., Okonkwo, J.O., Mamba, B.B. (2012) Potential application of activated carbon from maize tassel for the removal of heavy metals in water. Physics and Chemistry of the Earth, 50-52, 104-110.

[16] Bernard, E., Jimoh, A., Odigure, J.O. (2013) Heavy metals removal from industrial wastewater by activated carbon prepared from coconut shell. Research Journal of Chemical Sciences, 3(8), 3-9.

[17] Bello, O.S., Adegoke, K.A., Olaniyan, A.A., Abdulazeez, H. (2015) Dye adsorption using biomass wastes and natural adsorbents: Overview and future prospects. Desalination and Water Treatment, 53, 1292-1315.

[18] Abatal, M., Quiroz, A.T.V., Olguín, M.T., Vázquez-Olmos, A.R., Vargas, J., AnguebesFranseschi, F., Giácoman-Vallejos, G. (2019) Sorption of $\mathrm{Pb}(\mathrm{II})$ from Aqueous Solutions by 
Acid-Modified Clinoptilolite-Rich Tuffs with Different Si/Al Ratios. Applied Science, 9, 2415; doi:10.3390/app9122415

[19] Margeta, K., Zabukovec Logar, N., Šiljeg, M., Farkaš, A. (2013) Natural Zeolites in Water Treatment - How Effective is Their Use. In: Water Treatment (W. Elshorbagy and R.K. Chowdhury), In Tech, 81-112.

[20] Babel, S., Kurniawan, T. A. (2003) Low-cost adsorbents for heavy metals uptake from contaminated water: a review. Journal of Hazardous Materials, B97, 219-243.

[21] Inglezakis, V.J. (2005) The concept of "capacity" in zeolite ion-exchange systems. Journal of Colloid and Interface Science 281, 68-79.

[22] Pandová, I., Panda, A., Valícek, J., Harnicárová, M., Kušnerová, M., Palková, Z. (2018) Use of Sorption of Copper Cations by Clinoptilolite for Wastewater Treatment. International Journal of Environmental Research and Public Health, 15, 1364-1376.

[23] Turan, N.G., Ergun, O.N. (2009) Removal of $\mathrm{Cu}(\mathrm{II})$ from leachate using natural zeolite as a landfill liner material. Journal of Hazardous Materials, 167, 696-700.

[24] Mansoor, E., Van Der Mynsbrugge, J., HeadGordon, M., Bell, A.T. (2018) Impact of longrange electrostatic and dispersive interactions on theoretical predictions of adsorption and catalysis in zeolites. Catalysis Today, 312, 51-65.

[25] Corma, A. (2003) State of the art and future challenges of zeolites as catalyst. Journal of Catalysis, 216, 298-312.

[26] Motsi, T., Rowson, N.A., Simmons, M.J.H. (2009) Adsorption of heavy metals from acid mine drainage by natural zeolite. International Journal of Miner. Processing 92, 42-48.

[27] Panayotova, M.I. (2001) Kineticts and thermodynamics of coper ions removal from wastewater by use of zeolite. Waste Management, 21, 671-676.

[28] Stylianou, M.A., Inglezakis, V.J., Moustakas, K.G., Malamis, S.Ph., Loizidou, M.D. (2007) Removal of $\mathrm{Cu}(\mathrm{II})$ in fixed bed and batch reactors using natural zeolite and exfoliated vermiculite as adsorbents. Desalination, 215,133-142.

[29] Zhong, J., Han, J., Wei, Y., Tian, P., Guo, X., Song, C., Liu, Z. (2017) Recent advances of the nano-hierarchical SAPO-34 in the methanol-to-Olefin (MTO) reaction and other applications. Catalysis Science and Technology, 7, 4905-4923.

[30] Sprynskyy, M., Buszewski, B., Terzyk, A.P., Namie, J. (2006) Study of the selection mechanism of heavy metal $\left(\mathrm{Pb}^{2+}, \mathrm{Cu}^{2+}, \mathrm{Ni}^{2+}\right.$, and $\mathrm{Cd}^{2+}$ ) adsorption on clinoptilolite. Journal of Colloid and Interface Science, 304, 21-28.

[31] Jiang, N., Shang, R., Heijman, S.G., Rietveld, L.C. (2018) High-silica zeolites for adsorption of organic micro-pollutants in water treatment: A review. Water Research, 144, 145-161.

[32] Garrido-Ramírez, E., Theng, B., Mora, M. (2010) Clays and oxide minerals as catalysts and nanocatalysts in Fenton-like reactions-A review. Applied Clay Science, 47, 182-192.

[33] Reháková, M., C`uvanová, S., Dzivák, M., Rimár, J., Gaval'Ová, Z. (2004) Agricultural and agrochemical uses of natural zeolite of the clinoptilolite type. Current Opinion in Solid State and Materials Science, 8, 397-404.

[34] Bacakova, L., Vandrovcova, M., Kopova, I., Jirka, I. (2018) Applications of zeolites in biotechnology and medicine - a review. Biomaterials Science, 6, 974-989.

[35] Çulfaz, M., Yağız, M.(2004) lon exchange properties of natural clinoptilolite: LeadSodium and Cadmium-Sodium equilibria. Separation and Purification Technology, 37, 93-105.

[36] Perego, C., Bagatin, R., Tagliabue, M., Vignola, R. (2013) Zeolites and Related Mesoporous Materials for Multi-talented Environmental Solutions. Microporous and Mesoporous Materials, 166, 37-49.

[37] Cerjan-Stefanović, Š., Logar, N.Z., Margeta, K., Tušar, N.N., Arčon, I., Maver, K., Kovač, J., Kaučič ,V. (2007) Structural investigation of $\mathrm{Zn}^{2+}$ sorption on clinoptilolite tuff from the Vranjska Banja deposit in Serbia. 
Microporous and Mesoporous Materials, 105(3), 251-259.

[38] Allen, S.J., Ivanova, E., Koumanova, B. (2009) Adsorption of sulfur dioxide on chemically modified natural clinoptilolite. Acid modification. Chemical Engineering Journal 152, 389-395.

[39] Farkas, A., Rozic, M., Barbaric-Mikocevic, Z. (2005) Ammonium exchange in leakage waters of waste dumps using natural zeolite from the Krapina region, Croatia. Journal of Hazardous Materials, 117, 25-33.

[40] Ruggieri, F., Marín, V., Gimeno, D., Fernandez-Turiel, J.L., García-Valles, M., Gutierrez, L. (2008) Application of zeolitic volcanic rocks for arsenic removal from water. Engineering Geology, 101(3-4), 245-250

[41] Pilchowski, K., Chmielewská, E. (2003) Adsorptive separation of 1,2-dichloroethane from model wastewater by natural clinoptilolite. Acta Hydrochimica et Hydrobiologica 31, 249-252.

[42] Du, Q., Liu, S., Cao, Z., Wang, Y. (2005) Ammonia removal from aqueous solution using natural Chinese clinoptilolite. Separation and Purification Technology, 44, 229-234.

[43] Wang, S.B., Zhu, Z.H. (2006) Characterisation and environmental application of an Australian natural zeolite for basic dye removal from aqueous solution. Journal of Hazardous Materials, 136, 946952.

[44] Zendelska, A., Golomeova, M., Blazev, K., Krstev, B., Golomeov, B., Krstev, A. (2015) Adsorption of copper ions from aqueous solutions on natural zeolite. Environment Protection Engineering, 41, 17-36.

[45] Weiwei, A., Lu, L., Haifeng, Z., ShucDi, G., Xuechun, X., Guijuan, J., Guimei, G., Keyan, Z. (2013) Removal of $\mathrm{Cu}^{2+}$ from Aqueous Solutions Using Na-A Zeolite from Oil Shale Ash. Chinese Journal of Chemical Engineering, 21, 974-982.

[46] Soco, E., Kalembkiewicz, J. (2013) Adsorption of nickel (II) and copper(II) ions from aqueous solution by coal fly ash. Journal of Environmental Chemical Engineering 1, 581-588.

[47] Wang, S., Ariyanto, E. (2007) Competitive adsorption of malachite green and $\mathrm{Pb}$ ions on natural zeolite. Journal of Colloid and Interface Science 314, 25-31.

[48] Alpat, S.K., Ozbayrak, O., Alpat, S., Akcay, H. (2008) The adsorption kinetics and removal of cationic dye, Toluidine Blue 0 , from aqueous solution with Turkish zeolite. Journal of Hazardous Materials 151, 213-220.

[49] Armagan, B., Ozdemir, O., Turan, M., Celik, M.S. (2003) The removal of reactive azo dyes by naturaland modified zeolites. Journal of Chemical Technology and Biotechnology, 78, 725-732.

[50] Armagan, B., Ozdemir, O., Turan, M., Celik, M.S. (2004) Equilibrium studies on the adsorption of reactive azo dyes into zeolite. Desalination, 170, 33-39.

[51] Wang, S., Terdkiatburana, T., Tadé, M.O. (2008) Adsorption of $\mathrm{Cu}(\mathrm{II}), \mathrm{Pb}(\mathrm{II})$ and humic acid on natural zeolite tuff in single and binary systems. Separation and Purification Technology, 62, 64-70.

[52] Yousef, R.I., El-Eswed, B., Al-Muhtaseb, A.H. (2011) Adsorption characteristics of natural zeolites as solid adsorbents for phenol removal from aqueous solutions: Kinetics, mechanism, and thermodynamics studies. Chemical Engineering Journal, 171, 11431149.

[53] Abatal, M., Olguin, M.T. (2012) Evaluating of effectiveness of a natural and modified surface mexican clinoptilolite-rich tuff in removing phenol and p-nitrophenol from aqueous solutions. Environment Protection Engineering, 38(4), 53-64.

[54] Li, L.Y., Tazaki, K., Lai, R., Shiraki, K., Asada, R., Watanabe, H., Loretta, M.C., Chen, M. (2008) Treatment of acid rock drainage by clinoptilolite -Adsorptivity and structural stability for different $\mathrm{pH}$ environments. Applied Clay Science, 39, 1-9.

[55] Flanigen, E.M., Broach, R.W., Wilson, S.T. 
(2010) Zeolites in industrial separation and catalysis (Edited by $S$. Kulprathipanja), WILEY-VCH Verlag GmbH and Co. KGaA, Weinheim, USA, 1-26

[56] Alvarez-Ayuso, E., Garcia-Sanchez, A., Querol, X. (2003) Purification of metal electroplating waste waters using zeolites. Water Research, 37, 4855-4862.

[57] Motsi, T., Rowson, N.A., Simmons, M.J.H. (2011) Kinetic studies of the removal of heavy metals from acid mine drainage by natural zeolite. International Journal of Mineral Processing, 101, 42-49.

[58] Oren, A.H., Kayab, A. (2006) Factors affecting adsorption characteristics of $\mathrm{Zn}^{2+}$ on two natural zeolites. Journal of Hazardous Materials, B131, 59-65.

[59] Courh, S. (2008) The removal of zinc ions by natural and conditioned clinoptilolites. Desalination, 225, 41-57.

[60] Malandrinoa, M., Abollinoa, O., Giacominoa, A., Acetob, M., Mentasti, E. (2006) Adsorption of heavy metals on vermiculite: Influence of $\mathrm{pH}$ and organic ligands. Journal of Colloid and Interface Science, 299, 537-546.

[61] Bosso, S., Enzweiler, J. (2002) Evaluation of heavy metal removal from aqueous solution onto scolecite. Water Research, 36, 47954800.

[62] Panayotova, M. (2001) Kinetics and thermodynamics of removal of nickel ions from wastewater by use of natural and modified zeolite. Fresenius Environmental Bulletin, 10, 267-272.

[63] Farooq, U., Kozinski, J.A., Khan, M.A., Athar, M. (2010) Biosorption of heavy metal ions using wheat based biosorbents - A review of the recent literature. Bioresource Technology, 101, 5043-5053.

[64] Acheampong, M.A., Meulepas, R.J.W., Lens, P.N.L. (2010) Removal of heavy metals and cyanide from gold mine wastewater. Journal of Chemical Technology and Biotechnology, 85, 590-613.

[65] Ding, S.-I., Sun, Y.-z., Yang, C.-n., Xu, B.-h. (2009) Removal of copper from aqueous solutions by bentonites and the factors affecting it. Mining Science and Technology, 19, 489-492.

[66] Cincotti, A., Mameli, A., Locci, M.A., Orru, R., Cao, G. (2006) Heavy metal uptake by Sardinian natural zeolites: Experiment and modeling. Industrial and Engineering Chemistry Research, 45, 1074-1084.

[67] Gedik, K., Imamoglu, I. (2008) Affinity of clinoptilolite-based zeolites towards removal of $\mathrm{Cd}$ from aqueous solutions. Separation Science and Technology, 43, 1191-1207.

[68] Erdem E., Karapinar N., Donat R. (2004) The removal of heavy metal cations by natural zeolites. Journal of Colloid and Interface Science, 280(2), 309-314.

[69] Dal Bosco, S.M., Jimenez, R.S., Carvalho, W.A. (2005) Removal of toxic metals from wastewater by Brazilian natural scolecite. Journal of Colloid and Interface Science, 281, 424-431.

[70] Abatal, M., Olguin, M.T., Abdellaoui, Y., El Bouari, A. (2018) Sorption of Cd(II), Ni(II) and Zn(II) on natural, sodium-, and acid-modified clinoptilolite-rich tuff. Environment Protection Engineering, 44(1), 41-59.

[71] Bogdanovic G.D., Stankovic V., Antic D.V., Prodanovic S., Andric L., Vegner D. (2013) Adsorption of copper and zink ions from acid mine drainage by natural zeolite, In: XV Balkan Mineral Processing Congress, Sozopol, Bulgaria, Proceedings, 989-993.

[72] Kurniawan, T.A., Chan, G.Y.S., Lo, W.-h., Babel, S. (2006) Comparisons of low-cost adsorbents for treating wastewaters laden with heavy metals. Science of the Total Environment, 366, 409-426.

[73] Ziyath, A.M., Mahbub, P., Goonetilleke, A., Adebajo, M.O., Kokot, S., Oloyede, A. (2011) Influence of Physical and Chemical Parameters on the Treatment of Heavy Metals in Polluted Stormwater Using ZeoliteA Review. Journal of Water Resource and Protection, 3, 758-767.

[74] Milicevic, S., Povrenovic, D., Milosevic, V., Martinovic, S. (2017) Predicting the copper 
adsorption capacity on different zeolites. Journal of Mining and Metalurgy, 53 (A) (1), 57-63.

[75] Ouki, S., Kavannagh, M. (1997) Performance of Natural Zeolites for the Treatment of Mixed Metal-Contaminated Effluents. Waste Management and Research 15, 383-394.

[76] Oter, O., Akcay, H. (2007) Use of natural clinoptilolite to improve water quality: sorption and selectivity studies of lead(II), copper(II), zinc(II), and nickel(II). Water Environment Research 79, 329-335.

[77] Taamneh, Y., Sharadqah, S. (2017) The removal of heavy metals from aqueous solution using natural Jordanian zeolite. Applied Water Science, 7, 2021-2028.

[78] Peric, I., Trgo, M., Vukojevic Medvidovic, N. (2004) Removal of zinc, copper and lead bynatural zeolite-a comparison of adsorption isotherms. Water Research, 38, 1893-1899.

[79] Turkman, A.E., Aslan, S., Ege, I. (2004) Treatment of metal containing wastewaters by natural zeolites. Fresenius Environmental
Bulletin, 13, 574-580.

[80] Oren, A.H., Kaya, A. (2006) Factors affecting adsorption characteristics of $\mathrm{Zn}^{2+}$ on two natural zeolites. Journal of Hazardous Materials, B131, 59-65.

[81] Shaheen, S.M., Derbalah, A.S., Moghanm, F.S. (2012) Removal of Heavy Metals from Aqueous Solution by Zeolite in Competitive Sorption System. International Journal of Environmental Science and Development, 3(4), 362-367.

[82] Baker, H., Massadeh, A., Younes, H. (2009) Natural Jordanian zeolite: removal of heavy metal ions from water samples using column and batch methods. Environmental Monit Assess, 157, 319-330.

[83] Panayotova, M., Velikov, B. (2003) Influence of zeolite transformation in a homoionic form on the removal of some heavy metal ions from wastewater. Journal of Environmental Science and Health Part A: Toxic/Hazardous Substances \& Environmental Engineering, 38, 545-554.

\title{
PRIMENA PRIRODNIH ZEOLITA U TRETMANU OTPADNIH VODA - PREGLEDNI RAD
}

\section{Ž.Z. Tasić1, G.D. Bogdanovići" ${ }^{\prime \#}$ M.M. Antonijević ${ }^{1}$}

\author{
${ }^{1}$ University of Belgrade, Technical Faculty in Bor, V.J. 12, 19210 Bor, Serbia
}

(Primljen: 24. Oktobar 2019.; Prihvaćen: 25. Novembar 2019.)

\begin{abstract}
Izvod
Zagađenje životne sredine je značajan svetski problem. Velike količine zagađujućih supstanci, koje nastaju tokom različitih industrijskih procesa dospevaju do ekosistema. Na taj način teški metali, ulja i druga organska jedinjenja zagađuju vodene sisteme. Poznato je da su teški metali toksični po životnu sredinu. Osim toga, teški metali nisu razgardivi i mogu dospeti do živih organizama preko lanca ishrane. Među različitim metodama koje se koriste u tretmanu otpadnih voda, adsorpcija zauzima značajno mesto zbog jednostavnosti izvođenja procesa i efikasnosti u uklanjanju zagađujućih supstanci. Prirodni zeoliti iz različitih ležišta imaju dobru selektivnost prema jonima teških metala. Pored toga, prirodni zeoliti su ekološki prihvatljivi materijali, jeftini si i poseduju veliki kapacitet jonske izmene.
\end{abstract}

Ključne reči: Tretman otpadnih voda; Zagađujuće supstance; Prirodni zeolit; Adsorpcija. 